\title{
A iniciativa do magistrado para produção de provas no processo penal brasileiro conforme um olhar foucaultiano
}

\author{
The initiative of the magistrate on the production of evidence in the \\ Brazilian criminal proceedings from a foucaultian perspective
}

\author{
Alexandre Ribas de Paulo ${ }^{1}$ \\ Universidade Estadual de Maringá (UEM) - Maringá/PR, Brasil \\ ribasdepaulo@hotmail.com \\ http://lattes.cnpq.br/8924298565036412 \\ https://orcid.org/0000-0002-9655-538X
}

Valine Castaldelli Silva ${ }^{2}$

Universidade Federal de Santa Catarina (UFSC) - Florianópolis/SC, Brasil valine_cs@hotmail.com

lattes.cnpq.br/7414785543009632

https://orcid.org/0000-0001-6476-899X

1 Graduado em Direito pela Universidade Federal de Santa Catarina (UFSC); Mestre e Doutor em Direito pelo Programa de Pós-Graduação em Direito da Universidade Federal de Santa Catarina (PPGD/UFSC), na área de Direito, Estado e Sociedade. Realizou Estágio de Pós-Doutorado em Direito, Política e Sociedade pelo PPGD/UFSC. Atualmente é Professor Adjunto TIDE na Universidade Estadual de Maringá (UEM), lotado no Departamento de Direito Privado e Processual (DPP), lecionando a matéria de Direito Processual Penal II. Pesquisador do Ius Commune (Grupo de Pesquisa Interinstitucional em História da Cultura Jurídica - CNPq/UFSC), com ênfase em experiências jurídico-penais medievais e, também, do Grupo de Pesquisa intitulado "Problemas fundamentais do Direito Penal contemporâneo" (UEM). Coordenador do projeto de ensino "Grupo de Investigação sobre Punição (GIP)" e do projeto de extensão "Grupo de Diálogo Universidade-Cárcere-Comunidade (GDUCC)”, ambos da UEM.

2 Bacharel em Direito da Universidade Estadual de Maringá (2009-2013). Especialista em Ciências Penais pela mesma universidade (2014-2015). Mestre em Ciências Jurídicas pela Unicesumar (2016-2017). Doutoranda (2018) em Direito Internacional, Econômico e Comércio Sustentável pela Universidade Federal de Santa Catarina (UFSC). Pesquisadora vinculada do Grupo de Pesquisa Ius Gentium da UFSC. Docente na UNINGÁ. 


\section{Gabriel Orsini Maziero ${ }^{3}$}

Grupo Ibmec Educacional - São Paulo/SP, Brasil gabriel.orsini95@gmail.com

lattes.cnpq.br/1867029001288815

http://orcid.org/0000-0002-2965-7108

Resumo: O presente trabalho consiste em um estudo da construção do princípio da verdade real no processo penal brasileiro e suas implicações quanto a legitimidade ativa do magistrado na produção probatória, mediante o marco teórico das práticas sociais e do controle do discurso foucaultiano. A problemática da pesquisa surgiu com a constatação de que, após a promulgação da Constituição da República Federativa do Brasil de 1988, o atual Código de Processo Penal não passou por significativas reformas, persistindo as normas que dispõem sobre os poderes probatórios do juiz na persecução penal. O método utilizado é o indutivo. Por fim, tem-se que, a partir de um olhar foucaultiano, na realidade o discurso da busca por uma verdade real é uma estratégia conveniente às instituições que detêm a jurisdição penal, pois representa interesses escusos aos das partes e às finalidades das garantias e direitos fundamentais insculpidos na Constituição Federal de 1988.

Palavras-Chave: Michel Foucault; Princípio da verdade real; Direitos e garantias fundamentais; Direito Processual Penal; Iniciativa probatória do magistrado.

ABSTRACT: The present work consists of a study of the construction of the principle of real truth in the Brazilian penal process and its implications regarding the active legitimacy of the magistrate in the probative production, through the theoretical framework of social practices and the control of Foucaultian discourse. The research problem arose with the observation that after the promulgation of the Constitution of the Federative Republic of Brazil of 1988, the current Code of Criminal Procedure did not undergo significant reforms, and the rules that it lays down on the evidentiary powers

3 Bacharel em Direito pela Universidade Estadual de Maringá (2014-2018). Pós-graduando em Direito Processual Penal Lato Sensu pela Faculdade IBMEC São Paulo (2019). 
of the judge in criminal prosecution persist. The method used is inductive. Finally, it is evident that, from a Foucaultian point of view, in reality the discourse of the search for a real truth is a strategy that is convenient to the institutions that retain criminal jurisdiction, since it represents interests that are unfair to those of the parties and to the purposes of the guarantees and fundamental rights enshrined in the Federal Constitution of 1988.

KEYwORDs: Michel Foucault; Principle of real truth; Fundamental rights and guarantees; Criminal Procedural Law; Provisional initiative of the magistrate.

SUMÁRIO: Introdução; 1. Considerações sobre a construção da verdade real no processo penal para Michel Foucault; 2. A (i)legitimidade ativa do magistrado para a produção de provas no processo penal brasileiro; 3. A "verdade" decorrente do Código de Processo Penal. Considerações Finais; Referências.

\section{INTRODUÇÃo}

O estudo da verdade no campo do saber científico representa um dos temas de maior relevância e complexidade, graças a sua natureza filosófica, cuja abstração impede uma análise estritamente objetiva do assunto. O direito processual penal, longe de constituir qualquer exceção, também se ocupa do debate dessa questão no contexto de seus estudos.

Considerando a construção do princípio da verdade real no âmbito processual penal, com o presente trabalho pretende-se investigar os supostos poderes probatórios do magistrado criminal após a vigência do modelo constitucional de exercício da acusação criminal brasileira em 1988, adotando-se como referencial teórico para o desenvolvimento da pesquisa a análise do discurso jurídico através do modelo proposto por Michel Foucault, ora visto como instrumento de análise das práticas sociais, condições políticas, relações de poder e controle do próprio discurso.

O cerne problemático e que justifica a presente pesquisa consiste na compreensão de que o atual Código de Processo Penal (CPP) entrou em vigor em 1942, sob a égide do regime de exceção conhecido como Estado Novo (1937-1946) e mesmo após a promulgação de Constituições supervenientes, culminando com a atual e em vigor de 05 de outubro de 
1988, um novo diploma processual penal não foi editado, havendo apenas pontuais alterações nas vetustas regras que regulam o ius persequendi no Brasil. Desse modo, no que tange à produção probatória, que é o material processual imprescindível para a formação da convicção do julgador, as alterações realizadas no CPP encontram harmonia ou coerência com a ordem constitucional em vigor?

Embora a reformulação democrática declarada pela Constituição Federal de 1988 verse sobre toda a ordem jurídica, com especial destaque aos direitos e garantias fundamentais dos indivíduos quando se trata de persecução penal, ainda prevalecem, na prática, dispositivos normativos encontrados em um Código de Processo que apresenta contornos autoritários e que, em uma simples leitura, não poderiam ser entendidos como recepcionados pela ordem constitucional desde 1988.

Dessarte, delineiam-se duas hipóteses. A primeira: considerando que a Constituição Federal de 1988 adotou o sistema processual penal acusatório, bem ainda, levando em conta as ideias de Michel Foucault na interpretação do princípio da verdade real, não mais persistiriam os poderes probatórios ex officio do magistrado no processo penal brasileiro. A segunda hipótese consiste em: após a promulgação da Constituição Federal de 1988, em nada se alterou as disposições que tratam dos poderes probatórios de iniciativa do magistrado, assim como a linha teórica de Michel Foucault permite a aplicação do princípio da verdade real como mecanismo místico da manutenção da legitimidade estatal em sequestrar e disciplinar os indivíduos.

O método de abordagem considerado na presente pesquisa foi o indutivo ${ }^{4}$ e a técnica/procedimento de pesquisa utilizada foi a biblio-

4 Conforme Orides Mezzaroba e Cláudia Servilha Monteiro (2004, p. 62) “O método indutivo permite que possamos analisar nosso objeto para tirarmos conclusões gerais e universais. Assim, a partir, por exemplo, da observação de um ou de alguns fenômenos particulares, uma proposição mais geral é estabelecida para, por sua vez, ser aplicada a outros fenômenos. É, portanto, um procedimento generalizador." Sobre tal método, Rubem Alves (2002, p. 119) diz que: "[...] a indução tem como programa construir o discurso da ciência a partir dos fatos observados. É uma forma de argumentar, de passar de certas proposições para outras." E, concluindo, o mesmo autor afirma que a indução "[...] é uma forma de pensar que pretende efetuar, de forma segura, a passagem do visível para o invisível”. 
gráfica. ${ }^{5}$ Nesse sentido, como instrumento de pesquisa bibliográfica, buscaram-se obras pontuais em que o teórico Michel Foucault trata do tema da verdade e com relação às considerações sobre o princípio da verdade real, textos e livros em que juristas desenvolveram noções e conceitos a esse respeito.

No primeiro item far-se-á um apanhado geral das ideias que Michel Foucault desenvolve a respeito da verdade em algumas de suas obras, como A verdade e as formas jurídicas e $A$ ordem do discurso, buscando-se compreender o sentido e toda a trama de fatores que envolvem o termo para o teórico, também se realizará um paralelo entre o pensamento foucaultiano e a ciência jurídica. No segundo item será abordada a legitimidade ou ilegitimidade ativa do juiz criminal na produção de provas no ius persequendi sob a ótica definida a partir do item 1.

\section{Considerações sobre a Construção da VERDAde para Michel Foucault}

O teórico francês Michel Foucault é considerado um dos expoentes do pensamento filosófico do século XX. Pode-se dizer que suas obras e seus estudos são tratados em diversas áreas do conhecimento tendo em vista seus questionamentos acerca da existência e da constituição do sujeito.

Porquanto, adota-se a construção discursiva sobre a verdade de Michel Foucault como referencial teórico, em razão das suas importantes considerações a respeito das relações de poder e o controle do discurso, conferidos como uma ferramenta de análise das práticas sociais e de obtenção do conhecimento. ${ }^{6}$

5 A pesquisa bibliográfica, ou de fontes secundárias, terá por objetivo analisar o que foi escrito sobre o assunto tratado, a fim de permitir os meios para a análise das hipóteses elencadas. Nesse sentido consultar: LAKATOS; MARCONI, 1992, p. 43-4.

6 O presente artigo não possui a pretensão de esgotar a vastidão da obra de Michel Foucault. Sobre a complexidade desse marco teórico consultar: SANTOS; FRANÇA JÚNIOR; SANTOS, 2019. 
Ressalta-se que o autor ora tratado não foi um teórico do Direito $^{7}$ e não desenvolveu nenhuma teoria relacionada ao campo do Direito Processual Penal. Neste trabalho serão considerados suas lições apenas como instrumento de análise e compreensão do Direito como uma ciência que obedece a certos parâmetros e regras pré-estabelecidas. ${ }^{8}$

Na obra "A verdade e as formas jurídicas", originada de suas conferências proferidas no Brasil, entre os dias 21 a 25 de maio de 1973, organizadas pelo Departamento de Letras da PUC-Rio, Michel Foucault debruçou-se sobre a questão da verdade, o conhecimento, ou o que denominou como "domínios de saber".

Nessa toada, pode-se dizer que o teórico analisa a construção e o tratamento do tema da verdade no âmbito da filosofia moderna ocidental e apresenta uma nova perspectiva do conceito de verdade, colocando agora como fundamental o estudo deste tema dentro das relações de poder.

Foucault (2002, p. 11) pretende demonstrar que o sujeito do conhecimento, os domínios de saber e as formas de verdade são resultados das práticas sociais, condições políticas e econômicas de existência. E nesse contexto, ressalta a importância das formas jurídicas como influenciadoras das ordens de verdade obtidas, mais especificamente através da aplicação do ritual judiciário nos casos penais.

Portanto, para ele, certas formas de verdade poderiam ser obtidas a partir de formas judiciárias aplicadas na prática penal, conforme ocorreu com a utilização do inquérito em um determinado período da história (séculos XV ao XVIII), e após, com o surgimento do chamado exame (século XIX), como outro método de descobrimento da verdade (Ibidem, p. 12).

O inquérito, segundo Foucault, se originou de práticas políticas, administrativas e judiciárias, como forma de pesquisa da verdade, na

7 A obra de Foucault pode ser dividida em fases, sendo "A segunda fase é notoriamente a mais conhecida de Foucault, pois interagiu em maior proximidade com outros campos do saber (Direito, Medicina, Psicologia, Ciência Política) e pôde contribuir para a complexificação dos seus domínios de conhecimento. Sem dúvidas, a partir de então fica mais evidente a utilidade de sua filosofia para pensar as práticas de várias áreas.” (LEMOS, 2018, p. 27 e 31).

8 Nesse sentido consultar: PAULO, 2011, p. 22. 
medida em que o objetivo deste procedimento era saber quem foi o autor de certo fato, e quais as circunstâncias e momento (Idem).

É interessante observar quais foram os fatores que determinaram a alteração dos procedimentos judiciários de obtenção da verdade. Para Foucault (Ibidem, p. 72-3), nos procedimentos analisados, não se verificou a evolução da racionalidade humana, tal alteração é resultado de uma transformação política da época a qual o procedimento judicial está inserido; trata-se do que o autor define como um fenômeno político complexo, em que as relações de poder irão determinar as formas judiciais de busca da verdade.

Como conclusão, o escritor apresenta o "inquérito" como uma forma de saber, de descobrimento da verdade, totalmente vinculada ao poder político, relacionada ao exercício do poder. E mais, não só as relações de poder controlam os métodos de obtenção da verdade, mas também o procedimento judicial é considerado como um próprio instrumento de poder (Idem). ${ }^{9}$

Ainda no âmbito dessas instituições, Michel Foucault apresenta em sua obra "A ordem do discurso", que o poder está intimamente relacionado ao discurso através das instituições. Ou seja, o poder conferido ao discurso encontra seu fundamento, seu embrião, nas instituições. ${ }^{10}$

Na realidade, Foucault vai além ao apresentar a ideia do discurso. Para ele, trata-se de algo que é controlado, selecionado e organizado, nessa perspectiva, pode-se dizer que o autor defende que o discurso é

9 Nesse sentido, Gustavo Noronha de Ávila (2013, p. 16), analisando o contexto da utilização do modelo inquisitivo de persecução penal, retoma os ensinamentos de Michel Foucault para asseverar que a incorporação da ideia de verdade no procedimento judicial ocorre não por motivo de virtude, mas por uma questão de poder..

10 “O desejo diz: 'Eu não queria ter de entrar nesta ordem arriscada do discurso; não queria ter de me haver com o que tem de categórico e decisivo; gostaria que fosse ao meu redor como uma transparência calma, profunda, indefinidamente aberta, em que os outros respondessem à minha expectativa, e de onde as verdades se elevassem, uma a uma; eu não teria senão de me deixar levar, nela e por ela, como um destroço feliz'. E a instituição responde: 'Você não tem por que temer começar; estamos todos aí para lhe mostrar que o discurso está na ordem das leis; que há muito tempo se cuida de sua aparição; que lhe foi preparado um lugar que o honra mas o desarma; e que, se lhe ocorre ter algum poder, é de nós, só de nós, que lhe advém'." (FOUCAULT, 1996, p. 07.) 
um veículo de poder. E não só um veículo de poder, mas também um objeto de desejo, no qual aquele que detêm o discurso, possui igualmente o poder (Ibidem, p. 08-10).

Trazendo as considerações expostas para o contexto do presente trabalho, verifica-se que o Direito, ora considerado como uma ciência, seria então regido por um discurso científico que é controlado, selecionado e organizado.

E, seguindo a lógica foucaultiana, pode-se dizer que apenas certos indivíduos possuem o poder de fala no âmbito jurídico. Deveras, o autor aponta a existência de procedimentos internos de controle discurso que impõe a observação de determinadas regras para que o discurso seja considerado como aceito.

Desse modo, realizando um paralelo com as instituições que permeiam o âmbito jurídico, o Poder Judiciário como instituição oferece a figura do magistrado, neutro e imparcial como aplicador oficial do discurso legislativo para a resolução de litígios, inclusive na seara penal, onde o Estado é a "vítima" constante.

Em outras palavras, significa que em um procedimento submetido ao poder jurisdicional, ao final, será a pessoa do juiz quem representará a única verdade possível em um Estado de Direito e os indivíduos não possuem qualquer outra chance de resolver seus conflitos senão confiar na imparcialidade do julgador, que declarará o que é verdadeiro ou falso, realidade ou ilusão, justo ou injusto.

Nesse sentido, tem-se que a prestação jurisdicional, monopólio estatal, é submetido a uma série de regras de funcionamento, sendo que os sujeitos que compõem o processo devem obedecer a condições estabelecidas, principalmente no que se refere à aceitação da figura do juiz, ora qualificado como indivíduo capaz e responsável por revelar a prometida verdade.

Considerando que o poder conferido à decisão do magistrado é oriundo das mesmas normas que criam as instituições estatais, como se percebe no princípio da legalidade (artigo $5^{\circ}$, inciso XXXIX, da $\mathrm{CF}$ ) e da reserva legal (artigo 22, inciso I, da CF) fica evidente que a verdade revelada oficialmente pelo juiz, erga omnes, atende precipuamente ao que Foucault chama, na sua obra Do governo dos vivos, de regime de verdade: 
E por regime de verdade entendo o que força os indivíduos a um certo número de atos de verdade, no sentido que defini para vocês da última vez. Um regime de verdade é portanto o que constrange os indivíduos a esses atos de verdade, o que define, determina a forma desses atos e estabelece para esses atos condições de efetivação e efeitos específicos. Em linhas gerais, podemos dizer, um regime de verdade é o que determina as obrigações dos indivíduos quanto aos procedimentos de manifestação do verdadeiro. (FOUCAULT, 2014, p. 85)

Logo, pode-se notar que o discurso judiciário é imposto pela vontade de verdade ${ }^{11}$, cujas bases se encontram fixadas no sistema institucional, de modo que o ritual judiciário seleciona os sujeitos que devem participar do jogo processual penal para, sequestrando corpos e privando -os no cárcere - símbolo do poder punitivo contemporâneo - reafirmar o poder de conduzir as condutas dos homens.

Assim, dentro de procedimentos judiciais, o discurso é visto por Foucault como um instrumento de controle e produção da verdade. Deveras, a dissimulação da justificativa da busca por uma suposta verdade real é conveniente ao processo penal, pois representaria um discurso judiciário que atenderia a interesses que são escusos aos interesses das partes e às finalidades das garantias e direitos fundamentais dos indivíduos.

\section{A ( ()LEGITIMIDAdE ATIVA DO MAGISTRADO PARA A PRODUÇÃo DE PROVAS NO PROCESSO PENAL BRASILEIRO}

Sabe-se que o Código de Processo Penal atualmente em vigor na legislação brasileira foi promulgado em 03 de outubro de 1941, através

11 "Certamente, se nos situamos no nível de uma proposição, no interior de um discurso, a separação entre o verdadeiro e o falso não é nem arbitrária, nem modificável, nem institucional, nem violenta. Mas se nos situamos em outra escala, se levantamos a questão de saber qual foi, qual é constantemente, através de nossos discursos, essa vontade de verdade que atravessou tantos séculos de nossa história, ou qual é, em sua forma muito geral, o tipo de separação que rege nossa vontade de saber, então é talvez algo como um sistema de exclusão (sistema histórico, institucionalmente constrangedor) que vemos desenhar-se." Ibidem, p. 14. 
do Decreto-Lei no 3.689, no contexto Estado Novo (1937-1946), e mais ainda, inspirado no Códice Rocco italiano, de 1930, ou seja, de contornos notadamente autoritários. ${ }^{12}$

Após o regime militar, em 1988 uma nova ordem constitucional passou a vigorar no Brasil a partir da promulgação da chamada "Constituição Cidadã”, e com ela, o Estado Democrático de Direito como irradiador das estruturas jurídicas. ${ }^{13}$

Nesse contexto, tem-se que a Constituição é, no âmbito da dogmática jurídica, responsável por fixar "[...] com clareza as regras do jogo político e da circulação do poder [...]" (PRADO, 2005, p. 45).

12 Sobre o tema consultar: COUTINHO, 2010, p. 09; OLIVEIRA, 2017, p. 17. No mesmo sentido: "Sobre as características autoritárias do período do Estado Novo, justifica-se que nessa época foram suspensas liberdades e garantias individuais sob o pretexto de se preservar a ordem política vigente, sobretudo pelo fato de os Poderes Executivo e Legislativo terem sido concentrados nas mãos do Presidente da República, cuja necessidade da adoção do regime de exceção adveio do discurso da radicalização política dos partidos brasileiros da década de 30, que acabaram por empreender tentativas de tomada de poder, culminando em um estado de exceção permanente de oito anos sob o comando de Getúlio Vargas." (CHAMBÔ, 2013, p. 117-128). “Ainda, o Código de Processo Penal de 1941 substituiu o Código de Processo Criminal de 1832, este inspirado nas ideias iluministas da Europa ocidental e elaborado no contexto do Período Regencial brasileiro (1831-1840), sob o poder da chamada Regência Trina Permanente, composto pelos liberais moderados (representados pela aristocracia rural). Inicialmente, o referido Código foi responsável por impor uma política de descentralização do Poder Judiciário, haja vista que os representantes oficiais da jurisdição penal do Estado nessa época ganharam autonomia em nível local, sobretudo através da instituição dos Juízes de Paz, a fim de manter o indivíduo comum na condição de "súdito disciplinado e submisso às ordens do Estado através do império da lei, simbolizado pelo ius puniendi estatal e a obediência à legalidade soberanamente chancelada pelas luzes do século". Ocorre que, em 1840, com o início do chamado Segundo Reinado, de D. Pedro II, foi alterado o Código de Processo Criminal pela Lei ${ }^{\circ}$ 261, de 03 de dezembro de 1841, que acabou por centralizar a ação policial e judicial nas mãos do Imperador." (In: PAULO, 2008, p. 191-202)

13 Sobre a importância das Constituições assinala Geraldo Prado que: "O desenvolvimento do paradigma da modernidade radicou-se no ideal democrático, de modo que nada é mais natural que o relevo dado à Constituição entre as demais leis, decorrente do convencimento de que aquela assegura a divisão dos poderes do Estado, mediante sistema de freios e contrapesos, bem como tutela os direitos fundamentais, conformando toda ordem jurídica." (In: PRADO, 2005, p. 44). 
É truísmo afirmar-se que Constituição promove a mediação entre os sistemas políticos e os princípios processuais, bem como constitui o fundamento de validade de todas as leis e garante a proteção jurídica e social dos ideais da administração da justiça, funcionando como método de legitimação de composição dos conflitos e anteparos contra situações autoritárias (PRADO, 2005, p. 85).

Fixa-se aqui, portanto, um marco interpretativo para este tópico, que consiste em postular a Constituição Federal como estrutura democrática de existência e desenvolvimento da relação processual penal, ${ }^{14}$ devendo o modelo normativo vigente anterior ao ano de 1988 se adaptar a essa nova perspectiva, justamente pelo fato de a Constituição informar toda a ordem jurídica posta. ${ }^{15}$

A leitura das normas processuais penais também deve ser realizada sob a ótica constitucional, como forma de efetivação das garantias constitucionais. ${ }^{16}$ Isso porque, a concepção ideológica de um processo

14 Nesse sentido: “[...] os caminhos percorridos e os métodos utilizados no âmbito da instrução criminal são tão importantes quanto a necessidade de se fomentar o ideal de justiça. Nesse ambiente, que se pretende democrático, não haverá espaços para o vale-tudo. Respeitar limites é imprescindível. Obviamente que não é do que se convencionou chamar por impunidade que estamos a tratar. Em absoluto. Afirmamos, tão somente, que direitos e garantias fundamentais precisam ser respeitados, para que o poder de punir não seja exercido de forma arbitrária." (SANTOS; FRANÇA JÚNIOR; SANTOS, 2019, p. 19).

15 Sobre as balizas que a Constituição Federal de 1988 promoveu, ou deveria ter promovido, no processo penal: "É claro que essa reflexão deve ser compreendida dentro de certos limites quando se trata das práticas punitivas brasileiras que, historicamente, se mostraram refratárias à conformidade constitucional do processo penal, contrariando as decisões de caráter político assumidas em 1988, quando a República efetivamente foi fundada com a promulgação da Constituição. Mas esse sempre deve ser um horizonte a ser ferrenhamente perseguido por todos que estão comprometidos com a consolidação do Estado Democrático de Direito no País.” (KHALED JR, 2019).

16 Nesse sentido: $\mathrm{O}$ "[...] processo enquanto instrumento para atuação do direito de punir estatal, é condição para a legitimidade do resultado. Para tanto, o processo deve respeitar os parâmetros constitucionalmente previstos e se desenvolver com a perfeita observância das regras legais.” (BADARÓ, 2019); "Somente a partir da consciência de que a Constituição deve efetivamente constituir (logo, consciência de que ela constitui-a-ação), é que se pode compreender que o fundamento legitimante da existência do processo penal democrático se dá através da sua instrumentalidade constitucional. Significa 
penal democrático pressupõe a existência de um processo dialético, na qual está reservado ao juiz a função de julgar, mas sempre com a colaboração das partes, o que sacramenta as diretrizes do sistema acusatório (PRADO, 2005, p. 71).

E sobre a relação entre o sistema acusatório ${ }^{17}$ e a estrutura ideológica democrática, Geraldo Prado salienta:

Acreditamos sinceramente que a eleição ideológica do sistema acusatório é uma natural consequência das influências do princípio democrático em relação ao direito, uma vez que a separação dos poderes, projetando-se como mecanismo de viabilização da soberania popular, identifica nas atuações legislativa e judicial esferas distintas quanto à origem das respectivas investiduras, de sorte a conceber também modos diferentes de captação e orientação epistemológica e normativa das ações desenvolvidas em ambos os campos. (Ibidem, p. 71-2)

Aury Lopes Jr. (2014, p. 95), também compartilhando do entendimento de Geraldo Prado, assevera que o sistema acusatório é um imperativo do moderno processo penal, tendo em vista a atual estrutura social e política do Estado, pois assegura a imparcialidade e a tranquilidade psicológica do julgador, ${ }^{18}$ tratando, por consequência, o acusado como parte e não mais como mero objeto no processo penal.

Desse modo, portanto seria necessário que o Código de Processo Penal brasileiro fosse objeto da realização de um filtro constitucional,

dizer que o processo penal contemporâneo somente se legitima à medida que se democratizar e for devidamente constituído a partir da Constituição.” (LOPES JR, 2014, p. 33)

17 Mauro Fonseca Andrade (2013, p. 482) salienta que "A função dos sistemas processuais penais é servir como um instrumento de auxílio ao legislador, à hora de estabelecer a política criminal em âmbito processual. Eles são responsáveis por determinar o grau de eficiência da repressão criminal, o grau de imparcialidade dos juízes e o grau de tecnicidade da persecução penal.”

Em sentido contrário, porém abordando a iniciativa probatória no processo civil, Taruffo (2008) expõe que: "Evidentemente, los ordenamientos que le han atribuido al juez un papel activo en la adquisición de las pruebas han creído que tales poderes les eran otorgados a jueces capaces de desarrollar correctamente y racional su función de estímulo, de control y de iniciativa probatoria, sin que ello pusiera en peligro los valores fundamentales del proceso civil." 
de modo a adequar a persecução penal aos princípios, garantias e direitos fundamentais insculpidos no discurso prometido pela Constituição Federal, e mais ainda, dando ampla efetividade ao sistema acusatório. ${ }^{19}$

Realizando um estudo estritamente normativo, a Constituição Federal de 1988, muito embora não diga expressamente, teria adotado o sistema processual penal acusatório ${ }^{20} \mathrm{em}$ razão da norma contida em seu art. 129, I, ${ }^{21}$ a qual atribui ao Ministério Público o exercício privativo da ação penal pública, além dos demais dispositivos constantes no mesmo texto constitucional que garantem aos acusados o devido processo legal, ampla defesa e contraditório, preservação da presunção de inocência, além do respeito ao julgamento por juiz competente e imparcial (PRADO, 2005, p. 300-1). Ademais, ressalta-se que o sistema acusatório seria um dos pilares do sistema de garantias individuais postos pela Constituição de 1988 (OLIVEIRA, 2017 p. 19).

Nessa perspectiva, o processo é constituído de partes, no qual acusação e defesa se contraporiam em igualdade de posições, no qual

19 Sobre o fato de juristas como Guilherme de Souza Nucci, (2016.); Fernando da Costa Tourinho Filho, (2000); Rogério Lauria Tucci, (2011); que fundamentam o sistema processual brasileiro ser o misto, Aury Lopes Jr. (2014, p. 102.) assinala que "é absolutamente insuficiente, um reducionismo ilusório, até porque não existem mais sistemas puros (são tipos históricos), todos são mistos. Desse modo, o referido autor enfatiza que a partir deste reconhecimento deve-se identificar o princípio informador de cada sistema, para então classificá-lo como inquisitório ou acusatório. Alexandre Morais da Rosa (2013, p. 40) também compartilha do entendimento de que é um equívoco se falar em sistemas mistos, pela razão de que os ordenamentos jurídicos nacionais têm características de ambos os sistemas acusatório e inquisitório, não havendo sistemas puros.

20 Sobre a dificuldade de definição e identificação das características dos sistemas processuais penais: "Como se pode notar, a complexidade concernente às características dos sistemas processuais engendrou a busca por aquilo que seria o ponto nevrálgico de cada modelo, mas não obstaculizou a crença em sua concretização, muito menos na verificabilidade da verdade, mesmo que esta seja tão somente 'provável e opinativa', ou seja, uma 'verdade formal ou processual'.” (CARVALHO, 2017, p. 62). Outrossim, acerca dos sistemas processuais penais, consultar: ANDRADE, 2013.

21 "Art. 129. São funções institucionais do Ministério Público: I - promover, privativamente, a ação penal pública, na forma da lei.” (In: BRASIL, Brasília. Constituição da República Federativa do Brasil de 1988.Disponível em: < http:// www.planalto.gov.br/ccivil_03/constituicao/constituicaocompilado.htm>. Acesso em: 15 de novembro de 2018). 
haveria a presença de um juiz sobreposto em relação às partes, existindo a nítida separação de funções aos sujeitos processuais (BADARÓ, 2008, p. 37). Nesse sentido, a essência do sistema acusatório seria justamente a separação entre as funções de acusar, defender e julgar (Ibidem, p. 38). ${ }^{22}$ Nota-se, porém, que a contraposição das partes em posição igualitária parece um ideal a ser perseguido, pois, ao menos no cotidiano forense brasileiro, sabe-se que o Ministério Público conta com todo o aparato estatal em detrimento da defesa que, muitas vezes, é atomizada a uma débil manifestação formalmente "técnica" incapaz de impressionar a persuasão racional previamente consolidada pelo julgador.

Com efeito, o estudo das propriedades do sistema acusatório merece ir além. Acertadamente, os autores Aury Lopes Jr (Idem), Jacinto Coutinho (1998) Geraldo Prado (2005) e Alexandre Morais da Rosa (2013, p. 40), propõem que a gestão das provas por conta das partes durante todo o procedimento seria o fator fundante que representa fielmente $o$ sistema acusatório. Até porque, é “[...] na gestão da prova, que se revela a essência da opção pelo modelo processual” (GIACOMOLLI, 2008, p. 05).

$\mathrm{O}$ silogismo que se percebe dos discursos acadêmicos sobre o sistema processual penal brasileiro é que a atuação ativa do julgador na produção probatória subverte a principal característica do sistema acusatório, e invoca contornos notadamente inquisitivos, no qual o magistrado além de julgador é responsável pela acusação e pela defesa, por buscar

22 Nessa perspectiva Aury Lopes Jr. (2014, p. 93, 102) assevera que no sistema acusatório as figuras dos sujeitos de acusação, defesa e julgador são distintas e gozam de funções próprias. Mas, para ele, tal característica por si só não reproduz completamente a essência do modelo acusatório. Outrossim que "[...] o sistema acusatório apresenta as seguintes características: a) clara distinção entre as práticas de acusar e julgar; $\mathrm{b}$ ) a iniciativa probatória deve ser das partes (decorrência lógica da distinção entre as atividades); c) mantém-se o juiz como um terceiro imparcial, alheio a labor de investigação e passivo no que se refere à coleta da prova, tanto de imputação como de descargo; d) tratamento igualitário das partes (igualdade de oportunidades no processo); e) procedimento é em regra oral (ou predominantemente); f) plena publicidade de todo o procedimento (ou de sua maior parte); g) contraditório e possibilidade de resistência (defesa); h) ausência de uma tarifa probatória, sustentando-se a sentença pelo livre convencimento motivado do órgão jurisdicional; i) instituição, atendendo a critérios de segurança jurídica (e social) da coisa julgada; j) possibilidade de impugnar as decisões e o duplo grau de jurisdição.” (Idem) 
livremente elementos para seu próprio convencimento sobre a "verdade”. ${ }^{23}$ Khaled Jr. (2015, p. 04) admoesta sobre os vieses sub-reptícios de uma epistemologia inquisitória e suas consequências:

[...] o paradigma moderno oferece fundamentação e legitimação "científica" para práticas processuais que rompem com a estrutura do sistema acusatório, atribuindo ao juiz, enquanto sujeito do conhecimento, a capacidade de extração da essência das coisas. Trata-se de uma concepção de conhecimento que está esgotada e é considerada insuficiente no que se refere aos desafios que envolvem a complexidade do real. Sua adoção enquanto critério de produção da verdade em âmbito processual é desastrosa e apta a produzir enormes danos aos interesses do acusado, pois permite a sobrevivência de uma epistemologia inquisitória no interior de um processo que acaba sendo apenas formalmente acusatório, o que é manifestamente insuficiente para a desejável contenção regrada do poder punitivo.

\section{Contextualizando para o Código de Processo Penal brasileiro:}

[...] dispositivos que atribuam ao juiz poderes instrutórios, como o famigerado art. 156, incisos I e II, do CPP, externam a adoção do princípio inquisitivo, que funda um sistema inquisitório, pois representam uma quebra da igualdade, do contraditório, da própria estrutura dialética do processo. Como decorrência, fulminam a principal garantia da jurisdição, que é a imparcialidade do julgador. Está desenhado um processo inquisitório. (GIACOMOLLI, 2008, p. 108)

No que tange à existência de dispositivos que atribuem ao juiz brasileiro poderes probatórios, como é o caso dos artigos $156^{24} \mathrm{e}$

${ }^{23}$ Ferrajoli (2002, p. 619) aponta as distinções do sistema inquisitivo e acusatório: "I due metodi si distinguono piuttosto sulla base di due concezioni diverse sia del potere giudiziario che dela verità. Mentre il método inquisitório esprime uma fidúcia tendenzialmente illimitata nella bontà de potere e nella sua capacità di raggiungere il vero, il método accusatorio si caratterizza per uma sfiducia altrettanto illimitata nel potere quale autônoma fonte di verità.

24 Redação original do mencionado artigo: "Art. 156. A prova da alegação incumbirá a quem a fizer; mas o juiz poderá, no curso da instrução, ou antes de proferir sentença, determinar, de ofício, diligências para dirimir dúvida sobre ponto relevante." (BRASIL, Brasília. Decreto-Lei n. 3.689, de 3 de outubro de 1941. 
$209^{25}$, ambos do Código de Processo Penal, nota-se que são fruto de um processo penal do período histórico brasileiro conhecido como Estado Novo, considerado autoritário pelo autor, haja vista que a supressão das liberdades contava com o apoio do "Sistema de Justiça Penal", com fins ao atendimento dos interesses da "ditadura Vargas" (PRADO, 2005, p. 222).

Vale ressaltar, porém, que apesar de o autor supramencionado citar o art. 156, do Código de Processo Penal, como fruto do contexto do Estado Novo, constata-se um provável equívoco eis que o dispositivo sofreu alterações no ano de 2008 pela Lei $n^{\circ} 11.690$. Ocorre que, mesmo após quase vinte anos da edição da Constituição Federal, a referida alteração promovida pelo legislador infraconstitucional, ao invés de procurar adequar o dispositivo ao modelo constitucional de persecução penal em vigência, caminhou em sentido estranhamente contrário e deu ainda mais poderes probatórios ex officio ao juiz, permitindo-lhe agora a produção antecipada de elementos probatórios até mesmo sem a existência da invocação da jurisdição pelas partes legitimadas pela lei. ${ }^{26}$

Desse modo, a existência de poderes probatórios do juiz deduziria que a jurisdição penal estaria inserida no programa de segurança pública do Estado e não dirigida à defesa dos direitos individuais e garantias fundamentais previstos na Constituição Federal de 1988, que assegurariam o direito ao julgamento por juiz imparcial.

Código de Processo Penal. Disponível em: http://www.planalto.gov.br/ccivil_03/decreto-lei/Del3689Compilado.htm. Acesso em: 26 de março de 2020

"Art. 209. O juiz, quando julgar necessário, poderá ouvir outras testemunhas, além das indicadas pelas partes." (Idem)

Art. $1^{\circ}$ Os arts. 155, 156, 157, 159, 201, 210, 212, 217 e 386 do Decreto-Lei $\mathrm{n}^{\circ} 3.689$, de 3 de outubro de 1941 - Código de Processo Penal, passam a vigorar com as seguintes alterações: [...] "Art. 156. A prova da alegação incumbirá a quem a fizer, sendo, porém, facultado ao juiz de ofício: I - ordenar, mesmo antes de iniciada a ação penal, a produção antecipada de provas consideradas urgentes e relevantes, observando a necessidade, adequação e proporcionalidade da medida; II - determinar, no curso da instrução, ou antes de proferir sentença, a realização de diligências para dirimir dúvida sobre ponto relevante." (BRASIL, Brasília. Lei n. 11.690, de 9 de junho de 2008. Altera dispositivos do Decreto-Lei $n^{o} 3.689$, de 3 de outubro de 1941 - Código de Processo Penal, relativos à prova, e dá outras providências. Disponível em: http://www.planalto.gov.br/ccivil_03/ decreto-lei/Del3689Compilado.htm. Acesso em: 26 de março de 2020. 
Aliás, o próprio diploma constitucional, em seu art. 144, não menciona o juiz como parte integrante dos órgãos de segurança pública, já que esta será exclusivamente exercida através dos órgãos lá elencados. ${ }^{27}$ Logo, se for considerado que a legitimidade ativa do juiz na produção probatória representa anseios característicos do Código de Processo Penal de 1941, ora visto como instrumento de política de segurança pública do Estado, o acusado nunca seria julgado por um magistrado imparcial, mas por um membro do aparato estatal responsável por aplicar uma punição ao infrator da lei.

Ainda sobre a possibilidade de o julgador assumir o papel do órgão acusador quanto ao ônus probatório que lhe é reservado, assinalase que tencionar a igualdade entre as partes significaria a não permissão do magistrado em dublar a função acusatória (PACELLI, 2017, p. 20).

A igualdade das partes também é fundamento de impedimento da produção de provas pelo magistrado, de tal maneira que essa igualdade é uma garantia que decorre do "princípio da acusação" e significa paridade entre a defesa e acusação, sendo que a iniciativa probatória do julgador representaria uma quebra dessa garantia, na medida em que a confusão das funções de julgar e acusar provocaria o desequilíbrio da balança existente entre as partes (ROSA, 2013, p. 40-1).

E sobre as atividades da acusação e defesa que se contrapõem tem-se que é essencial para preservação da imparcialidade do julgador que ele não esteja envolvido psicologicamente com uma das versões em jogo (PRADO, 2005, 224-5). Isso porque:

O Juiz é destinatário da prova e, sem dúvida alguma, sujeito do conhecimento. Quando, porém, se dedica a produzir provas de ofício se coloca como ativo sujeito do conhecimento a empreender tarefa que não é neutra, pois sempre deduzirá a hipótese que pela prova pretenderá ver confirmada. Como as hipóteses do processo penal são duas: há crime e o réu é responsável ou isso não é

27 “À luz do art. 144, da Constituição Federal, a segurança pública será exercida através dos seguintes órgãos: polícia federal, polícia rodoviária federal, polícia ferroviária federal, polícias civis, polícias militares e corpos de bombeiros militares.” (BRASIL, Brasília. Constituição da República Federativa do Brasil de 1988. Disponível em: http://www.planalto.gov.br/ccivil_03/constituicao/ constituicaocompilado.htm. Acesso em: 26 de março de 2020). 
verdade, a prova produzida de ofício visará confirmar umas das duas hipóteses e colocará o juiz, antecipadamente, ligado à hipótese que pretende comprovar. (Idem)

Assim, se estamos falando de um sistema acusatório em total conformidade com as normas constitucionais, a imparcialidade do julgador só restará inteiramente respeitada quando se admitir que o ato de decidir a causa é resultado de uma consciente opção entre duas alternativas apresentadas pelas partes, às quais o juiz permaneceu equidistante durante todo o procedimento. ${ }^{28}$

Muito se discute sobre a lacuna probatória deixada pelas partes durante a instrução processual. A esse respeito, apesar de a atividade incompleta das partes na produção das provas ser reconhecida, tal inconveniente decorre da própria natureza do sistema acusatório, devendo o problema ser atenuado através do fortalecimento da estrutura dialética no processo, evitando-se sempre a atribuição de poderes instrutórios ao juiz (LOPES, p. 95). ${ }^{29}$

No que concerne às lacunas ou atividades incompletas deixadas pelas partes, ressalte-se que a concepção eficientista, meramente instrumental ou utilitária do processo, ainda que exista um certo consenso desta busca no conceito de jurisdição segundo o autor, não define a natureza específica da jurisdição no moderno Estado de Direito, pois o nexo entre legitimidade e verdade assegurado pelo esquema epistemológico e normativo prescinde desse anseio utilitário (PRADO, 2005, p. 73).

Assim, pode-se concluir que o denominado princípio da verdade real pertinente ao Direito Processual Penal brasileiro, numa perspectiva constitucional, não pode justificar a iniciativa ex officio do magistrado em

28 Nesse sentido: LOPES, 2014, p. 111; “[...] não faz qualquer sentido a ideia de que as partes devam entrar em contraditório com o juiz que deva julgá-las, ainda mais a respeito de uma prova produzida pelo próprio julgador." (KHALED JR., 2013, p. 150)

29 Em sentido diverso: "Se o acusador não produzir a prova dos fatos imputados, isto não implicará, necessariamente, a absolvição do acusado. Mesmo tendo permanecido inerte, não praticando o 'ato necessário para a satisfação do seu interesse', é possível que a consequência desfavorável - a condenação - não se verifique. A omissão do onerado poderá ser suprida pela atividade jurisdicional." (BADARÓ, 2003, p. 197). 
busca de provas para os autos. ${ }^{30}$ Trata-se de um ideal que se submete ao jogo político e das relações de poder ${ }^{31}$ que cede espaço a uma verdade imposta pelas regras de produção e funcionamento do discurso. Trata-se de uma verdade não absoluta, ${ }^{32}$ mas relativa à instituição a qual está ligada.

Portanto, somente seria legítima a prestação jurisdicional penal quando a verdade produzida no processo permitir uma decisão na qual o julgador tenha exercido um papel isonômico durante todo tempo, focando suas ações em apenas controlar o exercício pleno e efetivo do contraditório, deixando por conta das partes as atividades de convencimento, conforme determina o sistema constitucional acusatório de persecução penal.

\section{A "verdade" decorrente do Código de Processo Penal}

Como foi explorado no primeiro item, para Michel Foucault, o discurso se apresenta, dentro dos atos judiciais, como um instrumento de controle e produção da verdade, sendo que esta segue a determinadas regras, procedimentos e formas para que tenha validade.

Importante salientar que Foucault não compreende a Constituição Federal como se fosse um documento que encerraria todo o saber

30 Sobre a ambição de verdade: “[...] precisamos de controles mais rigorosos, para enfatizar as regras do jogo em detrimento de qualquer potencial ambição de verdade e com isso procurar superar uma epistemologia que é a expressão de uma violência contra o acusado e a realidade. Uma epistemologia da passeidade evidencia que a jurisdição penal somente pode se legitimar como estrutura de contenção do poder punitivo dedicada primordialmente à redução de danos, o que é absolutamente incompatível com a perspectiva de busca da verdade pelo juiz." (KHALED JR, 2015, p. 18).

31 Sobre o tema: "A partir de Foucault, seria preciso constatar que (a construção da) verdade e poder se entrelaçam, que ambos nutrem uma relação simbiótica. Nele, afirma-se que a verdade tem sido construída por meio de interações advindas do exercício de diversos poderes." (SANTOS; FRANÇA JÚNIOR; SANTOS, 2019, p. 22).

32 Nesse sentido: "A busca da verdade é compatível com o processo penal acusatório, desde que seja entendida como uma verdade cujo conhecimento estará inevitavelmente condicionado à falibilidade dos meios de reconstrução histórica, e que deve ser obtida respeitando as regras e as garantias processuais." (BADARÓ, 2019). 
político, jurídico e, portanto, fonte única de poder. Nas palavras do autor, na sua obra Sociedade punitiva (2015, p. 209), esclarece:

Portanto, é preciso fazer uma distinção não só entre os sistemas de poder e os aparatos estatais, como também, de forma geral, entre os sistemas de poder e as estruturas políticas. Isso porque a maneira como o poder é exercido numa sociedade não é descrita de modo adequado por estruturas políticas como o regime constitucional ou a representação dos interesses econômicos no aparato estatal. Há sistemas de poder muito mais amplos que o poder político em seu funcionamento estrito: todo um conjunto de focos de poder que podem ser as relações sexuais, a família, o emprego, a moradia. E o problema não é tanto saber se essas outras instâncias de poder repetem a estrutura do Estado. Pouco importa, no fundo, se a família reproduz o Estado ou vice-versa.

Essa constatação de Michel Foucault não se coaduna à hermenêutica garantista encontrada na dogmática processual penal brasileira, que, como visto, possui apego às normas constitucionais como se pudessem, por si mesmas, implementar e salvaguardar a mítica segurança jurídica aos jurisdicionados. ${ }^{33}$ Malgrado a Constituição seja limitadora dos poderes dos agentes estatais, é notável que o discurso narcisista oriundo do Poder Judiciário amolda as normas jurídicas às práticas jurídicas que lhe sejam mais convenientes.

Por exemplo, o desdém às garantias constitucionais aos acusados pode ser observada na recente decisão em medida liminar proferida pelo Ministro Luiz Fux, do Supremo Tribunal Federal, na Ação Direita de Inconstitucionalidade 6.299-DF ${ }^{34}$ que, ao negar vigência à existência do Juiz das Garantias - responsável pelo "controle da legalidade” e "pela salvaguarda dos direitos individuais” -, também determinou a suspensão, sem a devida motivação, do artigo 3-A, do Código de Processo Penal,

33 "[...] il processo, como del resto la pena, si giustifica precisamente in quanto técnica di minimizzazione dela reacione sociale al delito: di minimizzazione dela violenza, ma anche dell'arbitrio che altrimenti si produrrebbero in forme ancor più selvagge e sfrenate." (FERRAJOLI, 2002, p. 619)

34 BRASIL, Brasília. Ação Direta de Inconstitucionalidade n. 6.299. Disponível em: https://portal.stf.jus.br/processos/detalhe.asp?incidente=5840373. Acesso em: 26 de março de 2020. 
com a redação dada pela Lei 13.964/19: "O processo penal terá estrutura acusatória, vedadas a iniciativa do juiz na fase de investigação e a substituição da atuação probatória do órgão da acusação.”35

Percebe-se que a adoção expressa de um magistrado com atribuições constitucionais e limitado pelo sistema processual de estrutura acusatória ${ }^{36}$ se tornaria inconveniente para a manutenção do poder punitivo simbólico pelo Estado. Deveras, o aparato jurídico funciona, no Brasil, de maneira quase que mecânica para proceder a acusação e condenação dos indivíduos, não só pelo conhecido princípio da obrigatoriedade da ação penal pública - vinculado às atividades do Ministério Público, mas pela postura reiterada dos magistrados em replicar padrões decisórios autoritários sugeridos por Francisco Campos $^{37}$ na exposição de motivos do Código de Processo Penal (Decreto-Lei 3.689/41):

VII - [...] Por outro lado, o juiz deixará de ser um espectador inerte da produção de provas. Sua intervenção na atividade processual é permitida, não somente para dirigir a marcha da ação penal e julgar a final, mas também para ordenar, de ofício, as provas que lhe parecerem úteis ao esclarecimento da verdade. Para a indagação desta, não estará sujeito a preclusões. Enquanto não estiver averiguada a matéria da acusação ou da defesa, e houver uma fonte de prova ainda não explorada, o juiz não deverá pronunciar o in dubio pro reo ou o non liquet.

A recomendação da exposição de motivos é muito clara: o juiz deverá se abster de absolver o acusado no processo penal, exceto se tiver alguma prova de sua inocência e, para isso, deve ordenar "as provas que lhe parecerem úteis ao esclarecimento da verdade." Nessa perspectiva,

35 BRASIL, Brasília. Lei n. 13.964, de 24 de dezembro de 2019. Aperfeiçoa a legislação penal e processual penal. Disponível em: http://www.planalto.gov. br/ccivil_03/_ato2019-2022/2019/lei/L13964.htm. Acesso em: 26 de março de 2020.

36 Sobre a necessidade de previsão normativa expressa de qual sistema processual penal adotado no Brasil, consultar ANDRADE, 2013, P. 473-78.

37 O jurista mineiro Francisco Campos foi o redator da exposição de motivos do Código de Processo Penal, que curiosamente também elaborou a Constituição de 1937, impregnada com um autoritarismo exacerbado, inspirada na legislação fascista italiana e na Constituição polonesa (CHAMBÔ, 2013, p. 117-128). 
a conhecida anemia probatória, causadora da sentença absolutória com fundamento no artigo 386, inciso VII, do Código de Processo Penal, poderia sugerir uma sutil negligência do magistrado que não teria se empenhado suficientemente em descobrir a verdade legitimadora de uma punição ao delinquente.

Aqui há a necessidade de se mencionar um fato malsinado amiúde pela criminologia crítica (ANDRADE, 2003), em que o Estado é a vítima constante dos crimes em que ele mesmo possui a exclusividade em definir as condutas ilícitas dos indivíduos, legitimidade por autopoiese, e detém do monopólio em julgá-los e puni-los. Nas palavras do maior propagador dos ideais iluministas na seara criminal, Marques de Beccaria explicava:

Com efeito, no caso de um delito, há duas partes: o soberano, que afirma que o contrato social foi violado, e o acusado, que nega essa violação. É preciso, pois, que haja entre ambos um terceiro que decida a contestação. Êsse terceiro é o magistrado, cujas sentenças devem ser sem apêlo e que deve simplesmente pronunciar se há um delito ou se não há. (BECCARIA, 1959, p. 37)

Esse fenômeno da modernidade não passa despercebido por Michel Foucault, que esboça a gênese da ideia de que o crime seria uma questão de ordem pública e o soberano o representante da sociedade:

Além disso, há uma [espécie] de "elemento" - o crime como hostilidade social, o criminoso como inimigo público -, que não é nem elemento teórico nem elemento institucional ou prático, mas é o elemento comutador, o elemento conector entre essas duas séries, uma que leva à ideia de que o criminoso está em guerra com a sociedade, e a outra que é a da confiscação da justiça penal pelo poder monárquico. [...] Com efeito, a partir do fim do século XVIII, tem-se a instauração de toda uma série de instituições que vão, precisamente, instituir o personagem do criminoso como inimigo social e defini-lo na prática como tal: instituições do ministério público, da instrução, da ação judiciária, e organização de uma polícia judiciária, que permitirão que a ação pública se desenvolva a contento; [...] (FOUCAULT, 2015, p. 33)

Partindo-se do entendimento foucaultiano, onde a Constituição poderia ser vista como um instrumento discursivo de busca do saber, já 
que seu conteúdo disporia, fundamentalmente, sobre a estrutura política do Estado e de organização dos poderes, a "verdade" pertinente ao microcosmo jurídico criminal é que o juiz criminal tem a destinação normativa de combater os inimigos da sociedade ${ }^{38}$ e estes são, coincidentemente, os inimigos do Estado (DAL RI JÚNIOR, 2006).

Cogitando-se um mero esboço arqueológico, na cultura jurídica ocidental o magistrado não seria uma figura decorrente de uma constituição racionalmente escrita e fundada em valores democráticos, mas a replicação do próprio poder soberano. Aqui surge o papel do inquérito no âmbito jurídico:

[...] a partir do momento em que o inquérito se introduz na prática judiciária, traz consigo a importante noção de infração. Quando um indivíduo causa dano a um outro, há sempre, a fortiori, dano à soberania, à lei, ao poder. Por outro lado, devido a todas as implicações e conotações religiosas do inquérito, o dano será uma falta moral, quase religiosa ou com conotação religiosa. Tem-se assim por volta do século XII, uma curiosa conjunção entre lesão à lei e falta religiosa. Lesar o soberano e cometer um pecado são duas coisas que começam a se reunir. Elas estarão unidas profundamente no Direito Clássico. Dessa conjunção ainda não estamos totalmente livres. (FOUCAULT, 2002, p. 73-4)

A Constituição, portanto, não teria como encerrar a compreensão completa de todo um sistema de poder existente em determinada sociedade mas o fato é que, quando se trata do exercício da jurisdição no âmbito penal, os poderes utilizados pelo magistrado para produzir a verdade processual não decorrem do texto constitucional e sua base principiológica, mas sim pululam de forma sub-reptícia de um discurso antidemocrático ainda existente em um Código de Processo Penal que é notadamente antagônico aos direitos e garantias fundamentais

38 Sobre o enredamento da racionalidade no processo penal e a busca verdade: são “[...] meros inventos para justificar o mal. Desde a antiguidade, as tragédias, os castigos, tornaram-se festivais para a sociedade e para os julgadores que, em meio ao ritual do processo, agem como deuses, como se tivessem a vida humana sob o seu controle, podendo determinar o futuro a partir de uma visão parcial do passado, dizendo o que é a verdade e determinando quem é bom ou mal." (BOLDT; CARVALHO, 2017). 
constitucionais, mesmo que supervenientes. A nobre função de combate à criminalidade é, certamente, incompatível com a obrigação concomitante de "controle da legalidade" e de "salvaguarda dos direitos individuais" conforme a "estrutura acusatória" no processo penal.

Dessa maneira, retomando as questões trabalhadas por Michel Foucault, os procedimentos de exclusão do discurso, ${ }^{39}$ seleção dos sujeitos que falam, ${ }^{40}$ e a vontade de verdade amparada na instituição Poder Judiciário ${ }^{41}$ mostram que a produção probatória no Processo Penal atende aos interesses utilitários dos julgadores, representantes do Estado, revelando-se um instrumento cotidiano de relegitimação do Poder Judiciário como controlador e aplicador oficial das punições contra os delinquentes.

\section{Considerações Finais}

Pelo presente trabalho, buscou-se compreender a construção do princípio da verdade real no processo penal brasileiro e suas consequências sobre a legitimidade ativa do magistrado na produção probatória através do marco teórico das práticas sociais e do discurso apresentados por Michel Foucault.

Constata-se que, numa ótica foucaultiana, o discurso é tido como um instrumento de controle e produção da verdade dentro dos procedimentos judiciais, podendo-se afirmar que a estratégia da busca da verdade real no processo penal brasileiro é conveniente ao Poder Judiciário, como instituição, porque preserva o símbolo da autoridade punitiva estatal

39 Nega-se vigência aos dispositivos constitucionais em detrimento das normas processuais penais.

40 As provas e medidas cautelares muitas vezes são produzidas inaudita altera parte e sem manifestação do investigado/acusado. Nesse sentido, basta verificar o histórico da súmula vinculante $\mathrm{n}^{\mathrm{0}} 14 \mathrm{e}$, também, o instituto da mutatio libelli previsto no artigo 384, do Código de Processo Penal.

41 A relação entre verdade, processo penal e Foucault pode ser consultada em Boldt (2017): "A crença na capacidade processual de reprodução da verdade cumpre, com isso, uma função anestesiante importante para os atores processuais e para a sociedade, impedindo que a sentença judicial seja contestada, uma vez que traduz a realidade. Esse poder de estabelecer "o que é a realidade" escapa à perspectiva de que o conhecimento é construído, inventado, como afirma Foucault [...]." 
mantenedora de uma idealizada ordem social. No jogo processual penal brasileiro o dono do discurso oficial nunca perde, pois independentemente da decisão ser favorável ou não ao acusado, o que prevalece é a verdade revelada pelo magistrado.

A Constituição da República Federativa do Brasil de 1988, conforme a dogmática jurídica, adotou uma estrutura democrática de existência e desenvolvimento da persecução penal, sendo que o sistema acusatório seria o único sistema que atenderia a esse modelo. Nessa perspectiva, considerando que a busca da verdade no processo penal se submeteria ao jogo entre partes, isto é, indivíduos, o juiz não deveria atuar na produção probatória, ${ }^{42}$ sob pena de ofensa ao princípio da imparcialidade, deixando por conta das partes a incumbência de produzir provas.

Porém, como se nota no discurso que pode ser extraído da exposição de motivos do Código de Processo Penal e com apoio à visão histórica de Michel Foucault, pode-se concluir que a verdade processual penal, no âmbito jurídico brasileiro, é permeado por questões políticas e de relações de poder, sendo que o Código de Processo Penal é um instrumento preciso e hábil para produzir a "verdade" conveniente ao Estado, que possui o monopólio da jurisdição para definir obrigações, proibições e punições aos jurisdicionados como forma de preservar a direção e controle de todos os aspectos da existência dos indivíduos. Enfim, na prática processual penal brasileira a Constituição Federal de 1988 não foi recepcionada pelo Código de Processo Penal de 1941 e o magistrado criminal cotidianamente revela essa verdade.

\section{REFERÊNCIAS}

ALVES, Rubem. Filosofia da ciência: introdução ao jogo e a suas regras. São Paulo: Edições Loyola, 2002.

42 O processo criminal deveria ser “[...] um elemento limitador à investigação do real, sendo falaciosa a pretensão de transformá-lo em instrumento apto ao alcance de uma verdade absoluta. Não me parece possível ignorar a realidade imposta pela obediência aos métodos de acertamento regrados em nosso Estado Democrático de Direito. A reconstrução processual histórica permite, quando muito, o descortinamento de certos aspectos da verdade [...]." (KIRCHNER, 2009, p. 12) 
ANDRADE, Mauro Fonseca. Sistemas processuais penais e seus princípios reitores. Curitiba: Juruá, 2013.

ANDRADE, Vera Regina Pereira de. A ilusão de segurança jurídica: do controle da violência à violência do controle penal. Porto Alegre: Livraria do Advogado, 2003.

ÁVILA, Gustavo Noronha de. Falsas Memórias e Sistema Penal: a prova testemunhal em xeque. Rio de Janeiro: Lumen Juris, 2013.

BADARÓ, Gustavo Henrique Righi Ivahy. Direito processual penal. Tomo I. Rio de Janeiro: Elseiver, 2008.

BADARÓ, Gustavo Henrique. Epistemologia judiciária e prova penal [livro eletrônico]. São Paulo: Thomson Reuters Brasil, 2019.

BADARÓ, Gustavo Henrique Righi Ivahy. Ônus da prova no processo penal. São Paulo: Editora Revista dos Tribunais, 2003.

BECCARIA, Cesare. Dos delitos e das penas. São Paulo: Atena, 1959.

BOLDT, Rafael; CARVALHO, Thiago Fabres de. Para além do processo: epistemologia inquisitória e a ilusão do sistema acusatório na modernidade. Revista Brasileira de Ciências Criminais, vol. 134/2017, p. 323-49, ago. 2017.

CARVALHO, Raphael Boldt de. Processo penal e catástrofe: entre as ilusões da razão punitiva e as imagens utópicas do abolicionismo. Tese (Doutorado em Direito) - Faculdade de Direito de Vitória-RJ, 2017.

CHAMBÔ, Pedro Luiz. O estado de exceção como regra - Um estudo históricoconstitucional do Estado Novo (1937-1945). Revista da Faculdade de Direito, Universidade de São Paulo, v. 108, p. 117-128, 22 nov. 2013.

COUTINHO, Jacinto Nelson de Miranda; CARVALHO, Luis Gustavo Grandinetti Castanho de. O Novo processo penal à luz da Constituição (Análise crítica do Projeto de Lei no 156/2009, do Senado Federal). Rio de Janeiro: Lumen Juris, 2010.

COUTINHO, Jacinto Nelson de Miranda. Introdução aos princípios gerais do direito processual penal brasileiro. Revista da Faculdade de Direito UFPR, Curitiba, a. 30, n. 30, 1998, p. 163-98. http://dx.doi.org/10.5380/rfdufpr.v30i0.1892

DAL RI JÚNIOR, Arno. O estado e seus inimigos: a repressão política na história do direito penal. Rio de janeiro: Revan, 2006.

FERRAJOLI, Luigi. Diritto e ragione: Teoria del garantismo penale. Roma: Editori Laterza, 2002. 
FOUCAULT, Michel. A verdade e as formas jurídicas. Tradução de Roberto Cabral de Melo Machado e Eduardo Jardim Morais. Rio de Janeiro: NAU Editora, 2002.

FOUCAULT, Michel. A ordem do discurso: Aula Inaugural no Collège de France, pronunciada em 2 de dezembro de 1970. Tradução de Laura Fraga de Almeida Sampaio. São Paulo: Edições Loyola, 1996.

FOUCAULT, Michel. Do governo dos vivos. São Paulo: WMF Martins Fontes, 2014.

GIACOMOLLI, Nereu José. Reformas (?) do processo penal - Considerações críticas. Rio de Janeiro: Lumen Juris, 2008.

KHALED JR., Salah H. A produção analógica da verdade no processo penal. Revista Brasileira de Direito Processual Penal, Porto Alegre, vol. 1, n. 1, p. 166-184, 2015. http://dx.doi.org/10.22197/rbdpp.v1i1.9

KHALED JR., Salah H. A busca da verdade no processo penal: para além da ambição inquisitorial. São Paulo: Editora Atlas, 2013.

KHALED JR., Salah H; DIVAN, Gabriel Antinolfi. A captura psíquica do juiz e o sentido da atividade probatória no processo penal contemporâneo. Revista Brasileira de Ciências Criminais, vol. 156/2019, p. 395-423, jun. 2019.

KIRCHNER, Felipe. A utopia da verdade real: compreensão e realidade no horizonte da hermenêutica filosófica. Revista Brasileira de Ciências Criminais, vol. 80/2009, p. 119-149, 2009.

LAKATOS, Eva Maria; MARCONI, Marina de Andrade. Metodologia do trabalho cientifico: procedimentos básicos, pesquisa bibliográfica, projeto e relatório, publicação e trabalhos científicos. São Paulo: Atlas, 1992.

LEMOS, Clécio José Morandi de Assis. Foucault e o abolicionismo penal. Tese (Doutorado em Direito) - Pontifícia Universidade Católica do Rio de Janeiro, Rio de Janeiro-RJ, 2018.

LOPES JR, Aury. Direito Processual Penal [livro eletrônico]. São Paulo: Saraiva, 2014.

MEZZAROBA, Orides; Cláudia Servilha Monteiro. Manual de metodologia da pesquisa no direito. São Paulo: Saraiva, 2004.

NUCCI, Guilherme de Souza. Manual de processo penal e execução penal [livro eletrônico]. Rio de Janeiro: Forense, 2016.

OLIVEIRA, Eugênio Pacelli. Curso de processo penal [livro eletrônico]. São Paulo: Atlas, 2017. 
PAULO, Alexandre Ribas de. O discurso jurídico-penal iluminista no direito criminal do império brasileiro. In: DAL RI JÚNIOR, Arno et al. Iluminismo e direito penal. Florianópolis: Fundação Boiteux, 2008, p. 191-202.

PAULO, Alexandre Ribas de. O jus puniendi germânico na Alta Idade Média italiana: o Reino dos Longobardos. Tese (Doutorado em Direito) - Universidade Federal de Santa Catarina, Florianópolis-SC, 2011.

PRADO, Geraldo. Sistema Acusatório: A Conformidade Constitucional das Leis Processuais Penais [livro eletrônico]. Rio de Janeiro: Editora Lumen Juris, 2005.

ROSA, Alexandre Moraes de. Guia compacto do processo penal conforme a teoria dos jogos. Rio de Janeiro: Lumen Juris, 2013.

SANTOS, Bruno C. L.; FRANÇA JÚNIOR, Francisco A.; SANTOS, Hugo L. R. Práticas judiciárias no campo criminal e a construção das verdades na persecução penal: um debate a partir de Michel Foucault. Revista Brasileira de Direito Processual Penal, Porto Alegre, vol. 5, n. 2, p. 1041-1072, mai./jun. 2019. https://doi. org/10.22197/rbdpp.v5i2.199

TARUFFO, Michele. Poderes probatorios de las partes y del juez en Europa. Revista Ius et Praxis, 12 (2): 95-122, 2006. http://dx.doi.org/10.4067/ S0718-00122006000200005

TOURINHO FILHO, Fernando da Costa. Processo Penal. São Paulo. Saraiva, 2000. v. 1 .

TUCCI, Rogério Lauria. Direitos e garantias individuais no processo penal brasileiro. São Paulo: Editora Revista dos Tribunais, 2011. 


\section{Informações adicionais e declarações dos autores (integridade científica)}

Declaração de conflito de interesses (conflict of interest declaration): os autores confirmam que não há conflitos de interesse na realização das pesquisas expostas e na redação deste artigo.

Declaração de autoria e especificação das contribuições (declaration of authorship): todas e somente as pessoas que atendem os requisitos de autoria deste artigo estão listadas como autores; todos os coautores se responsabilizam integralmente por este trabalho em sua totalidade.

- Alexandre Ribas de Paulo: redação (writing - original draft), revisão crítica com contribuições substanciais (writing review and editing), aprovação da versão final.

- Valine Castaldelli Silva: projeto e esboço inicial (conceptualization), desenvolvimento da metodologia (methodology), revisão bibliográfica participação ativa nas discussões dos resultados (validation), revisão crítica com contribuições substanciais (writing - review and editing), aprovação da versão final.

- Gabriel Orsini Maziero: projeto e esboço inicial (conceptualization), desenvolvimento da metodologia (methodology), coleta e análise de dados (data curation), levantamento bibliográfico (investigation), revisão bibliográfica (investigation), redação (writing - original draft), participação ativa nas discussões dos resultados (validation), aprovação da versão final.

Declaração de ineditismo e originalidade (declaration of originality): os autores asseguram que o texto aqui publicado não foi divulgado anteriormente em outro meio e que futura republicação somente se realizará com a indicação expressa da referência desta publicação original; também atestam que não há plágio de terceiros ou autoplágio. 
Dados do processo editorial

(http://www.ibraspp.com.br/revista/index.php/RBDPP/about/editorialPolicies)

- Recebido em: 22/09/2019

Equipe editorial envolvida

- Controle preliminar e verificação de plágio: 28/11/2019

- Avaliação 1: 02/12/2019

- Editor-chefe: 1 (VGV)

- Editor-assistente: 1 (RDG)

- Avaliação 2: 16/12/2019

- Revisores: 3

- Avaliação 3: 20/12/2019

- Decisão editorial preliminar: 28/02/2020

- Retorno rodada de correções 1: 14/03/2020

- Decisão editorial preliminar 2: 15/03/2020

- Retorno rodada de correções 2: 26/03/2020

- Decisão editorial final: 27/03/2020

\section{COMO CITAR ESTE ARTIGO:}

PAULO, Alexandre R.; SILVA, Valine C.; MAZIERO, Gabriel O. A iniciativa do magistrado para produção de provas no processo penal brasileiro conforme um olhar foucaultiano. Revista Brasileira de Direito Processual Penal, Porto Alegre, vol. 6, n. 2, p. 995-1024, mai./ago. 2020. https://doi.org/10.22197/rbdpp.v6i2.280

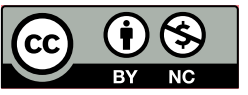

Esta obra está licenciada com uma Licença Creative Commons Atribuição-NãoComercial 4.0 Internacional. 